\title{
Malignancy Algorithms in The Preoperative Assessment of Suspicious Adnexal Masses During Pregnancy
}

\section{Gebelikteki Şüpheli Adneksiyal Kitlelerin Preoperatif Değerlendirmesinde Malignite Algoritmaları}

\author{
Yağmur Minareci¹, Özgür Aydın Tosun², Naziye Ak³, Hamdullah Sözen4, Samet Topuz4, Mehmet Yavuz Salihoğlu \\ 1Eskisehir City Hospital, Department of Gynecologic Oncology, İstanbul, Turkey \\ 2Istanbul Medeniyet University, Goztepe Research and Training Hospital, Department of Gynecology and Obstetrics, Division of Gynecologic Oncology, İstanbul, Turkey \\ 3Istanbul University, Institute of Oncology, Department of Medical Oncology, İstanbul, Turkey \\ 4Istanbul University, Faculty of Medicine, Department of Gynecology and Obstetrics, Division of Gynecologic, İstanbul, Turkey
}

$\ddot{O} Z$

GíRiș ve AMAÇ: Bu çalışmanın amacl, adneksiyal kitlesi olan gebelerde üç farklı algoritmanın etkinliğini değerlendirmek ve bu algoritmaları gebelikteki duyarlllı ve özgüllügünü karşılaştırmaktır.

YÖNTEM ve GERECLER: : Retrospektif çalısmamızda, Aralık 1999 - Arallk 2019 tarihleri arasında İstanbul Üniversitesi Kadın Hastalıkları ve Doğum Anabilim Dalı Jinekolojik Onkoloji Bilim Dalı'na gebeliği esnasında şüpheli adneksiyal kitle saptandiğı için başvuran ve bu sebeple opere edilen kadınlar değerlendirdi.

BULGULAR: Bu çalışmaya dahil edilen adneksiyal kitle olan 40 gebe vardl. Onbirinde (\% 30) benign, altisinda (\% 15) borderline ve yirmi üçünde (\% 55) malign lezyon mevcuttu. 450 eşik değerinde RMI4 algoritmasl; 0,21 duyarlılığa, 0,91 özgülüğe sahipti. >\%10 eşik değerinde, LR2 ve ADNEX algoritmalarının her ikisinin de duyarlillğ $1.00 \mathrm{idi}$, ancak, LR2 algoritmasinın özgüllü̈̆ü 0.55; ADNEX algoritmasının özgüllü̈̆̈̈ 0.82 idi. Pozitif prediktif değerler (PPV) RMI4 için 0.86, LR2 için 0.85 ve ADNEX algoritması için 0.94 iken; negatif prediktif değerler (NPV) RMI4 için 0.30, LR2 ve ADNEX algoritmaları için 1.00 idi. RMI4 ile hem LR2 hem de ADNEX algoritmasl arasindaki fark istatistiksel olarak anlamliydl (her ikisi için de $p<0.001$ ). Ancak LR2 ve ADNEX algoritmaları arasındaki fark anlamlı değildi $(p=0.25)$.

TARTIŞMA ve SONUÇ: ADNEX ve LR2 algoritmaları, adneksiyal kitlesi olan gebelerde malign tümörleri benign lezyonlardan ayirt etmede yüksek hassasiyete sahipti. Ek olarak, ADNEX en yüksek özgüllüğe sahipti. Bununla birlikte, RMI4 algoritmast, adneksiyal kitlesi olan gebelerde en düşük performansa sahipti.

Anahtar Kelimeler: RMI, ADNEX, logistic regression model 2, LR2, gebelik, adneksiyal kitle

Iletişim / Correspondence:

Yağmur Minareci

Eskisehir City Hospital, Department of

Gynecologic Oncology, Ístanbul, Turkey

dryagmurminareci@gmail.com

Basvuru Tarihi: 05.02.2021

Kabul Tarihi: 02.09.2021

\section{ABSTRACT}

INTRODUCTION: The aim of the present study was to evaluate the effectiveness of the three different algorithms on pregnant women who had adnexal mass, and also, to compare the sensitivity and specificity of these algorithms in pregnancy.

METHODS: Our retrospective study evaluated the women who had a suspicious adnexal mass during pregnancy consulted to the Division of Gynecologic Oncology and underwent surgery at the Department of Obstetrics and Gynecology, Istanbul University from December 1999 to December 2019.

RESULTS: There were forty pregnant women with adnexal mass. Eleven (30\%) has benign, six (15\%) had borderline, and twentythree (55\%) had malign lesions. The RMI4 algorithm had a sensitivity of 0.21 , a specificity of 0.91 , at a cut-off point $\geq 450$. At a cut-off $>\% 10$, the LR2 and ADNEX algorithms both had a sensitivity of 1.00, however, LR2 algorithm had a specificity of 0.55; ADNEX algorithm had a specificity of 0.82. Positive predictive values (PPV) were 0.86 for RMI4, 0.85 for LR2 and 0.94 for ADNEX algorithm, and negative predictive values (NPV) were 0.30 for RMI4, 1.00 for LR2 and ADNEX algorithms. The difference between RMI4 and both LR2 and ADNEX algorithm was statistically significant ( $p<0.001$ for all). However, the difference between the LR2 and ADNEX algorithm was not significant $(p=0.25)$.

DISCUSSION AND CONCLUSION: The ADNEX and LR2 algorithms had high sensitivity in differentiating malignant tumors from benign lesions on pregnant women with adnexal mass. In addition, ADNEX had the highest specificity of all. However, RMI4 algorithm had the poorest performance on pregnant women with adnexal mass.

Keywords: RMI, ADNEX, lojistic regression model 2, LR2, pregnancy, adnexial mass
Doi: $10.5505 / \mathrm{ktd} .2021 .54715$

Minareci Y: 0000-0003-1420-9318

Tosun Ö. A.: 0000-0001-8067-669X

Ak N.: 0000-0001-5790-7066

Sözen H.: 0000-0003-1894-1688

Topuz S. : 0000-0002-9069-0185

Salihoŏlu Y. M.: 0000-0003-2801-9339 


\section{INTRODUCTION}

Adnexal mass is a very common situation in premenopausal women and is usually diagnosed incidentally. Since adnexal mass has a malignant potential, this condition requires a detailed evaluation and gynecologic oncologist consultation frequently. Therefore, clinical evaluation and management are of prognostic importance. On the other hand, adnexal mass during pregnancy may be diagnosed at a rate of $4 \%$ to $25 \%$ in the first trimester (1). However, most of them are benign cystic lesions and resolves by time, leaving a persistent mass of $0.7 \%$ to $1.7 \%$ (2). Finally, the diagnosis rate of malign adnexal mass during pregnancy reaches approximately $3 \%$ in this cohort (3), and the management strategy becomes even more critical due to the potential adverse maternal and fetal outcomes. Thus, surgical management carries the potential risks for both mother and fetus, while observational management has the risks of tumoral spread and potential torsion, rupture, or hemorrhage. Effective and accurate methods are needed for the detection of malignant lesions during pregnancy. However, there is a limited number of diagnostic tools available. Serum CA125 is not reliable in pregnancy. Ultrasonography with doppler feature is considered the gold standard, nevertheless, the main limitation of ultrasound is its examiner-dependent nature. Magnetic Resonance Imaging (MRI) may be an efficient complement to ultrasound however, gadolinium use is associated with the increased risk of fetal anomalies. Nonetheless, amidst the Covid-19 pandemic, it is not possible for all pregnant women with suspected adnexal mass to be examined by expert sonographers and even scanned with MRI.

In such situations, various algorithms have been developed to facilitate the diagnosis of suspicious adnexal masses along with ultrasound findings. The Risk of Malignancy Index (RMI) is one of the wellknown algorithms in the evaluation of adnexal masses. RMI has four modifications and RMI4 is the most recommended one $[4,5]$. The Logistic Regression model 2 (LR2) has been developed in collaboration with the International Ovarian Tumor Analysis (IOTA) to detect malignant lesions that could easily be used by non-expert sonographers. Lastly, the Assessment of Different NEoplasias in the adneXa (ADNEX) algorithm which has been recently developed by IOTA is the most complex one. However, these algorithms were only tested on non-pregnant women.

The aim of the present study was to evaluate the effectiveness of the three different algorithms on pregnant women who had adnexal mass. In addition, we aimed to compare the sensitivity and specificity of these algorithms in pregnancy.

\section{MATHERIAL AND METHODS}

We retrospectively evaluated the women who had a suspicious adnexal mass during pregnancy and consulted to the Division of Gynecologic Oncology at Istanbul Medical Faculty, Istanbul University between December 1999 and December 2019. Inclusion criteria were a) pregnant women who had a suspicious adnexal mass(es) from 6th gestational week to 42th gestational week and consulted to our Gynecologic Oncology Clinic, b) women who underwent surgery due to suspicious adnexal mass(es) at the hospital of Istanbul Medicine Faculty during pregnancy or early postpartum period. Exclusion criteria were a) pregnant women who were conservatively managed due to suspicious adnexal mass(es) b) pregnant women who met the inclusion criteria but had missing data.

$\underline{\text { Table 1. Histologic diagnosis of the cases }}$

\begin{tabular}{|l|c|}
\hline Diagnosis & $\mathbf{n}(\boldsymbol{\%})$ \\
\hline Malignant tumors & $23(57.5)$ \\
\hline serous adenocarcinoma & $7(17.5)$ \\
\hline mucinous adenocarcinoma & $5(12.5)$ \\
\hline disgerminoma & $4(10)$ \\
\hline clear cell carcinoma & $2(5)$ \\
\hline endometrioid adenocarcinoma & $1(2.5)$ \\
\hline immature teratoma & $1(2.5)$ \\
\hline sertoli-leygig cell tumour & $1(2.5)$ \\
\hline cystic mesothelioma & $1(2.5)$ \\
\hline leiomyosarcoma & $1(2.5)$ \\
\hline Borderline serous tumor & $6(15)$ \\
\hline Benign lesions & $11(27.5)$ \\
\hline mature cystic teratoma & $5(12.5)$ \\
\hline serous cystadenoma & $3(7.5)$ \\
\hline mucinous cystadenoma & $2(5)$ \\
\hline endometrioma & $1(2.5$ \\
\hline \hline Total & $\mathbf{4 0}(\mathbf{1 0 0})$ \\
\hline
\end{tabular}

Demographic data, ultrasonographic findings, indications for surgery, surgical technique, peroperative findings, and final diagnosis were recorded.

The score of RMI4 algorithm was calculated as the product of $(\mathrm{U}) \times(\mathrm{M}) \times(\mathrm{S}) \times \mathrm{CA} 125$ value; ultrasound feature $(\mathrm{U})$ comprised of five variables which were suggestive for malign lesions: the 
presence of multilocular cystic lesion, solid areas, bilaterality, ascites, and signs of intra-abdominal metastases.

One point was given for each variable, and if the sum of the points was $\leq 1, U=1$; and if the sum of the points was $>1$, then $U=4$; menopausal status (M) was presumed 1 point as all women were pregnant; tumor size (S) was measured by ultrasound for each patient, and a lesion size $<7 \mathrm{~cm}$ assigned as 1 point, lesion size $\geq 7 \mathrm{~cm}$ assigned as 2 points; serum CA125 levels were measured preoperatively in the biochemistry laboratory of our institution, and CA125 value (IU/mL) was applied to algorithm directly. Finally, a cut-off level of 450 points was set for RMI4 algorithm. The probability score of LR2 Algorithm was calculated by the mobile application (IOTA models v2013 for iOS) which was developed by IOTA collaboration. Six variables were entered including age, presence of ascites, acoustic shadowing, papillary projections with detectable blood flow, irregular cyst wall and maximum diameter of largest solid component in millimeters ( $\mathrm{mm}$ ), and the result was expressed as a percentage, the cut-off level was set to $0.10(10 \%)$. The score of ADNEX Algorithm was calculated by web application which was also developed by IOTA collaboration. Nine variables were entered including age, presence of ascites, acoustic shadowing, number of locules in cystic lesion, maximal diameter of lesion in $\mathrm{mm}$, maximal diameter of largest solid part in $\mathrm{mm}$, number of papillary projections, CA125 value (in $\mathrm{UI} / \mathrm{mL}$ ), and the status of the center (referral gynecologic oncology center or not). The result was expressed as a percentage and the cut-off level was set to 0.10 (10\%). All patients examined by at least one senior gynecologic oncology consultant and expert ultrasonographer before surgery, and then the surgery decision was made. The institutional review board and ethics committee approved our study protocol (ethics number: 1449, date: 2019) and waive the requirement to obtain informed consent due to retrospective nature.

The SPSS software v20 was used for data interpretation and statistical analysis. Borderline tumors were accepted as malignant for statistical analysis. We calculated sensitivity, specificity, positive predictive value (PPV), negative predictive value (NPV), and the area under the receiveroperating characteristics curve (AUC) for the cutoff points of 450 points for RMI 4 and $10 \%$ for both
LR2 and ADNEX algorithms. The McNemar test was used to test the statistical significance of differences in sensitivity and specificity between the various algorithms when an AUC could not be calculated. The kappa coefficient $(\kappa)$ analysis test was performed to determine the compatibility of the results of each evaluation system with postoperative pathology. In determining the degree of compatibility, a kappa coefficient $(\kappa)$ of 0.20 is accepted as slight, $0.21-0.40$ is as fair, $0.41-0.60$ is as moderate, $0.61-0.80$ is as substantial and $>0.80$ is as perfect. A p-value $<0.05$ was considered statistically significant.

\section{RESULTS}

There were forty pregnant women with adnexal mass included in the present study. Eleven (30\%) has benign, six (15\%) had borderline, and twentythree (55\%) had malign lesions. One woman had bilateral masses which were malignant. Twentyfive women underwent laparotomy during pregnancy. Among them, surgery was performed at the third trimester in one woman (33 weeks), at the second trimester in seventeen women (median 18 weeks, range 14-24), and at the first trimester in seven women (median 12 weeks, range 8-13). Thirteen women underwent exploratory surgery at the time of cesarean section (median 38 weeks, range 37-39). Two women underwent laparotomy after vaginal delivery due to eclampsia and acute renal failure.

None of the surgery was performed under emergency conditions. Adnexectomy and frozen section were the most common procedures followed by lymph node dissection, omentectomy, and hysterectomy. Cystectomy was performed in five cases which were all benign lesions. Fertility preserving surgery was performed in ten women which spared the uterus and contralateral adnexa. Patient characteristics and the data of ultrasound features used in the different algorithms were shown in Table 1. The most common benign lesion was mature cystic teratoma and the most common malignant lesion was serous adenocarcinoma. Histologic diagnoses were given in Table 2.

RMI4, LR2, and ADNEX algorithms were retrospectively applied to all cases. The RMI4 algorithm had a sensitivity of 0.21 , a specificity of 0.91 , at a cut-off point $\geq 450$. The AUC for the overall discrimination between benign and 
malignant tumors for RMI4 was 0.73 (95\% CI, 0.55-0.91). At a cut-off $>\% 10$, the LR2 and ADNEX algorithms both had a sensitivity of 1.00, however, LR2 algorithm had a specificity of 0.55 ; ADNEX algorithm had a specificity of 0.82 . The AUC for the overall discrimination between benign and malignant tumors for LR2 and ADNEX were 0.82 (95\% CI, 0.66-0.99) and 0.90 (95\% CI, 0.761.0), respectively (Figure 1). Positive predictive values (PPV) were 0.86 for RMI4, 0.85 for LR2 and 0.94 for ADNEX algorithm, and negative predictive values (NPV) were 0.30 for RMI4, 1.00 for LR2 and ADNEX algorithms (Table 3). The difference between RMI4 and both LR2 and ADNEX algorithm was statistically significant ( $p$ $<0.001$ for all). However, the difference between the LR2 and ADNEX algorithm was not significant $(\mathrm{p}=0.25)$. According to kappa co-efficient interpretation, it was observed that the ADNEX algorithm score was perfect (0.87), LR2 algorithm score was substantial (0.64), and RMI4 algorithm score was slight $(0.07)$.

\section{DISCUSSION}

The effectiveness of RMI4, LR2, and ADNEX algorithms to detect malignant adnexal mass in pregnant women was the main target in the present study. The three algorithms were compared in terms of sensitivity and specificity. To our knowledge, this is the first study that demonstrates that pregnant women with adnexal mass can be triaged using these algorithms. On the other hand, it was shown that ADNEX and LR2 algorithms had high sensitivity in differentiating malignant tumors from benign lesions in our cohort. Additionally, ADNEX had the highest specificity and RMI4 algorithm had the worst performance on pregnant women.

Adnexal masses are generally detected in the first two trimesters in pregnancy. However, functional lesions regress spontaneously, thus 65$80 \%$ of patients remain asymptomatic (6). Unfortunately, malignant lesions may be encountered and have an incidence of $0.002-0.008$
(7). Ultrasonography with Doppler feature is the first modality of choice in evaluating adnexal masses during pregnancy. However, as stated above, the main problem with ultrasonography is its examiner-dependent nature. The sonographer should be familiar with the characteristics of the suspicious lesion to be malignant. Therefore, the need for an experienced sonographer is the weakest point of this imaging modality. MRI is the modality of choice where the ultrasonography is insufficient. MRI may be an effective complement to ultrasonography, particularly when the solid lesions are evaluated. On the other side, during pregnancy, gadolinium should be used in situations where the benefits frankly outweigh the potential risks (8). Moreover, MRI is an expensive imaging modality, and is not available in every healthcare unit. Lastly, CA125 is a tumor marker that increases in most women with epithelial ovarian cancer. However, during pregnancy, CA 125 is also produced by the placenta, and peak serum levels are reached at the end of the first trimester, followed by a gradual decrease with advancing pregnancy (9). Accordingly, altered serum levels of CA125 make the interpretation difficult in pregnant women.

The main challenge in pregnant women with adnexal mass is whether she should be managed surgically or conservatively. For benign lesions, conservative management is preferable, and surgery is usually needed in the case of torsion, rupture, or hemorrhage. However, for malignant lesions, extensive surgery is generally essential, and should be performed in an oncology center, preferably. This has a critical importance of increasing the survival (10,11). In a such situation when differentiating malignant from benign adnexal masses, an experienced sonographer may not always be available and so does MRI. Therefore, various algorithms have been developed to facilitate the diagnosis of suspected adnexal masses using ultrasound findings obtained by less experienced sonographers/clinicians. RMI is such an algorithm that many current guidelines recommend its use in women with adnexal masses $(12,13)$. 
Table 2. Patient characteristics and ultrasound features of the forty pregnant women with adnexal mass

\begin{tabular}{|c|c|c|c|}
\hline Variable & $\begin{array}{l}\text { Benign Lesions } \\
\qquad(\mathrm{n}=11)\end{array}$ & $\begin{array}{l}\text { Borderline Tumors } \\
\qquad(\mathrm{n}=6)\end{array}$ & $\begin{array}{c}\text { Malignant Tumors } \\
(\mathrm{n}=\mathbf{2 3})\end{array}$ \\
\hline Age, years (range) & $30(25-43)$ & $27(26-29)$ & $27(17-43)$ \\
\hline CA $125(\mathrm{U} / \mathrm{mL})$ (range) & $29(12-259)$ & $42(8-64)$ & $45(16-1460)$ \\
\hline \multicolumn{4}{|l|}{ Ultrasound Score $^{\ddagger}$} \\
\hline 1 & 7 & 1 & 11 \\
\hline 4 & 4 & 5 & 12 \\
\hline \multicolumn{4}{|l|}{ Laterality } \\
\hline left unilateral & 6 & 1 & 10 \\
\hline right unilateral & 5 & 4 & 12 \\
\hline bilateral & 0 & 0 & 1 \\
\hline Maximum diameter of lesion in milimeters (range) & $60(26-160)$ & $81(45-95)$ & $88(18-300)$ \\
\hline \multicolumn{4}{|l|}{ Type of Tumor } \\
\hline Unilocular & 1 & 1 & $\mathbf{0}$ \\
\hline Multilocular & 4 & 1 & 1 \\
\hline Unilocular-solid & 2 & 1 & 4 \\
\hline Multilocular-solid & 3 & 3 & 10 \\
\hline Solid & 1 & 0 & 7 \\
\hline Unclassifiable & 0 & 0 & 1 \\
\hline $\begin{array}{l}\text { Maximum diameter of solid lesion in milimeters } \\
\text { (range) }\end{array}$ & $27(15-50)$ & $15(5-25)$ & $\mathbf{0}$ \\
\hline \multicolumn{4}{|l|}{ Number of locules } \\
\hline$<\mathbf{1 0}$ & 10 & 6 & 14 \\
\hline$\geq 10$ & 1 & 0 & 9 \\
\hline \multicolumn{4}{|l|}{ Number of papillary projections } \\
\hline none & & & 9 \\
\hline 1 & 1 & 2 & 5 \\
\hline 2 & 1 & 1 & 4 \\
\hline 3 & 0 & 0 & 3 \\
\hline$>\mathbf{3}$ & 0 & 0 & 2 \\
\hline \multicolumn{4}{|l|}{ Blood flow in papillary projections } \\
\hline yes & 2 & 2 & 13 \\
\hline no & 9 & 1 & 1 \\
\hline Presence of irreguler cystic wall & 4 & 4 & 13 \\
\hline Presence of metastasis & 0 & 0 & 2 \\
\hline Presence of acoustic shadowing & 3 & 0 & $\mathbf{0}$ \\
\hline Presence of ascites & 0 & 0 & 2 \\
\hline $\begin{array}{l}\text { Pregnancy trimester at the time of diagnosis median } \\
\text { (range) }\end{array}$ & $2(1-2)$ & $2(1-3)$ & $2(1-3)$ \\
\hline $\begin{array}{l}\text { Pregnancy week at the time of diagnosis median } \\
\text { (range) }\end{array}$ & $17(7-22)$ & $18(10-31)$ & $20(6-39)$ \\
\hline Gravida (range) & $2(1-4)$ & $2(2)$ & $2(1-7)$ \\
\hline Parity (range) & $1(0-2)$ & $1(1)$ & $1(0-4)$ \\
\hline \multicolumn{4}{|l|}{ Timing of Surgery } \\
\hline At first trimester & $2^{\dagger}$ & 0 & 5 \\
\hline At second trimester & 7 & 4 & 6 \\
\hline At third trimester (excluding birth) & 0 & 0 & 1 \\
\hline concurrent with caesarean section & $2^{¥}$ & 2 & 9 \\
\hline After vaginal delivery & $\mathbf{0}$ & $\mathbf{0}$ & 2 \\
\hline
\end{tabular}

either of the patients had non-viable pregnancy, dilatation \& curettage was concomitantly performed at the end of surgery, $\not$ according to RMI4 algoritm, ¥ one patient denied to surgical management at the time of diagnosis in the second trimester. 
Table 3. Diagnostic results of the three algorithms used in differentiation between malignant and benign adnexal masses during pregnancy

\begin{tabular}{|l|c|c|c|c|}
\hline $\begin{array}{l}\text { Assessment } \\
\text { method }\end{array}$ & $\begin{array}{c}\text { Sensitivit } \\
\mathbf{y}\end{array}$ & Specificity & $\mathbf{P P V}^{\dagger}$ & $\mathbf{N P V}^{\ddagger}$ \\
\hline $\mathrm{RMI}^{4}$ & 0.21 & 0.91 & 0.86 & 0.30 \\
& $(0.11-$ & $(0.87-$ & $(0.72-$ & $(0.23-$ \\
& $0.30)$ & $0.94)$ & $0.90)$ & $0.36)$ \\
\hline $\mathrm{LR}^{2}$ & 1.00 & 0.55 & 0.85 & 1.00 \\
& $(0.96-$ & $(0.47-$ & $(0.77-$ & $(0.98-$ \\
& $1.00)$ & $0.60)$ & $0.92)$ & $1.00)$ \\
\hline ADNEX & 1.00 & 0.82 & 0.94 & 1.00 \\
& $(0.97-$ & $(0.78-$ & $(0.90-$ & $(0.98-$ \\
& $1.00)$ & $0.87)$ & $0.97)$ & $1.00)$ \\
& & & & \\
\hline
\end{tabular}

PPV: Positive predictive value, + NPV: Negative predictive value, Values in parentheses are 95\% CI; ADNEX: Assessment of Different NEoplasias in the adneXa; LR2: Logistic Regression 2, and Risk of Malignancy Index 4 (RMI4). For both ADNEX and LR2 algorithm, cutoff value of $\geq 0.1(\geq 10 \%)$, and for RMI4 algorithm, cut-off value of $\geq 450$ was used.

RMI4, developed by Yamamoto et al., is a subtype of the RMI algorithm that takes into account the size of the lesion during the risk calculation (4). RMI4, is a simple and useful algorithm, has increased sensitivity and positive predictive value compared to other RMI subtypes $(4,5)$. LR2 Algorithm has been developed by IOTA to differentiate malignant lesions using simple sonographic findings. LR2 is an efficient and easyto-apply algorithm that uses the findings obtained by sonographers with average experience and skill. Age is the only variable among the six variables in the LR2 algorithm that is not related to sonographic findings. A recent meta-analysis reported by Myes et al. revealed that RMI algorithm had worse performance than LR2 algorithm in discriminating benign lesions from malignant tumors, and they finally concluded that LR2 algorithm could be used as an alternative in the absence of an expert sonographer (14). In another meta-analysis comparing RMI and LR2 by Kaijser et al., significantly higher sensitivity and specificity were shown in favor of LR2 in premenopausal women (15). Lastly, ADNEX algorithm is the most recent algorithm which has nine variables. Three of them are clinical variables including age, serum CA125 level, and status of the health center. The remaining six variables include sonographic findings that can be easily obtained by a non-expert sonographer. Meys et al. and Viora et al. reported that ADNEX algorithm could be applicable in women with suspicious adnexal mass particularly when an expert sonographer was not Available $(16,17)$.

Finally, a recent meta-analysis including 4905 patients which compared all three algorithms had revealed that ADNEX was the best algorithm to distinguish between a malignant tumor and benign lesion in women who had an adnexal mass (18).

Figure Legend: Distribution of the results of the three algorithms.
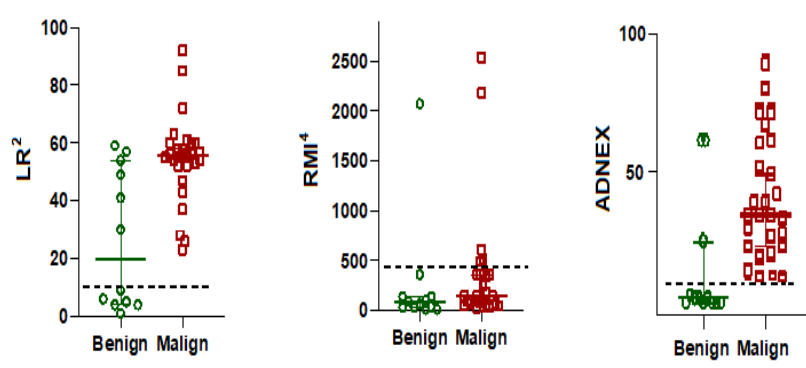

ADNEX: Assessment of Different NEoplasias in the adneXa; LR2: Logistic Regression 2, and Risk of Malignancy Index 4 (RMI4). For both ADNEX and LR2 algorithm, cut-off value of $\geq 0.1$ ( $\geq 10 \%)$, and for RMI4 algorithm, cut-off value of $\geq 450$ was used.

The other main issue is that these algorithms have never been used before in pregnant women with adnexal mass. On the other hand, amidst the Covid-19 pandemic, it is not possible for all pregnant women who have suspected adnexal mass to be examined by expert sonographers. For the same reasons, it is not always possible to perform MRI to these patients. Under these circumstances, we consider that there is a need for an easy-to-apply algorithm which may be performed by non-expert sonographers/ clinicians to provide triage in pregnant women with adnexal mass. Thus, pregnant women with adnexal mass which has a high risk of malignancy may be consulted with gynecological oncologists for surgical evaluation. In our article, we aimed to evaluate the effectiveness of different algorithms which was developed to detect ovarian malignancy for non-pregnant women, on pregnant women with adnexal mass. These algorithms designed to be used in daily clinical practice. We had twenty-nine pregnant women with ovarian tumor (borderline + malignant) and eleven women with benign lesions. The worst results were achieved with RMI4 which was able to detect only five of twenty-nine patients with ovarian tumor and reported one of eleven women with a benign mass as malignant. The sensitivity and NPV were only $20.7 \%$ and 30.3, respectively. Accordingly, almost four-fifths of malignant masses may be misdiagnosed as benign and lead to improper treatment, thereby, the spread of the tumor. Thus, the sensitivity of RMI4 was unacceptably low. LR2 had favorable results and was able to detect all twenty-nine patients with malignant tumors. 
However, five of eleven women with a benign mass were reported as malignant. The specificity and PPV were $54.5 \%$ and $85.3 \%$ respectively.

Lastly, ADNEX had the best results, and was able to detect all twenty-nine patients with malignant tumors. Two of eleven women with a benign mass were reported as malignant. The specificity and PPV increased to $81.8 \%$ and $93.5 \%$, respectively. Finally, we concluded that using LR2 and ADNEX algorithms, absolute risk estimates for malignant tumors including borderline tumors and benign lesions could be obtained with very accurate results on pregnant women compared to RMI4 algorithm $(\mathrm{p}<0.001)$. Both LR2 and ADNEX algorithms can be applied in the triage of pregnant women with adnexal mass in the absence of expert sonographer/ clinicians and MRI facilities. However, RMI4 algorithm was found inadequate in differentiating malignant tumors from benign lesions on pregnant women.

There are some limitations in our study which should be discussed. Firstly, there were a small number of patients in our study, therefore it is insufficient to draw a definitive conclusion. Secondly, due to its retrospective nature, there might be undetected bias, indeed the prevalence of malignant lesions was

high in our cohort. Finally, all the algorithms were developed for non-pregnant women and have never been applied to pregnant women.

For this reason, our results must be validated by prospective studies. On the other hand, the strength of the study was that it was conducted in a single reference center. In fact, conducting the study in a single center had been an advantage due to the establishment of the standard protocol for each case. Thus, patients were managed by the experienced team (including sonographers and gynecologic oncologist) might be considered as a strength of the present study. Also, to our knowledge, these algorithms are evaluated in detailed for pregnant patients, firstly.

In conclusion, ADNEX and LR2 algorithms had high sensitivity in differentiating malignant tumors from benign lesions on pregnant women with adnexal mass. In addition, ADNEX had the highest specificity of all. However, RMI4 algorithm had the poorest performance on pregnant women with adnexal mass.
Ethics Committee Approval: İstanbul University

Medicine Faculty Clinical Research Ethics Committee (06.12.2019 date and 20 number)

Conflict of Interest: There is no conflict of interest.

Funding: There is no financial support.

Informed Consent: This a retrospective study

\section{REFERENCES}

1. Condous G, Khalid A, Okaro E, Bourne T. Should we be examining the ovaries in pregnancy? Prevalence and natural history of adnexal pathology detected at first trimester sonography. Ultrasound in Obstetrics and Gynecology: The Official Journal of the International Society of Ultrasound in Obstetrics and Gynecology. 2004;24(1):62-66.

2.Yazbek J, Salim R, Woelfer B, Aslam N, Lee CT, Jurkovic D. The value of ultrasound visualization of the ovaries during the routine 11-14 weeks nuchal translucency scan. Eur J Obstet Gynecol Reprod Biol. 2007 Jun;132(2):154-8.

3.Kohler M. The adnexal mass in pregnancy. Postgrad Obstet Gynecol. 1994;14(12):1-5.

4. Yamamoto $\mathrm{Y}$, Yamada R, Oguri H, Maeda N, Fukaya T. Comparison of four malignancy risk indices in the preoperative evaluation of patients with pelvic masses. Eur J Obstet Gynecol Reprod Biol. 2009 Jun;144(2):163-7.

5.Alanbay I, Akturk E, Coksuer H, Ercan M, Karasahin E, Dede M, et al. Comparison of risk of malignancy index (RMI), CA125, CA 19-9, ultrasound score, and menopausal status in borderline ovarian tumor. Gynecol Endocrinol. 2012 Jun;28(6):478-82.

6.Hoover K, Jenkins TR. Evaluation and management of adnexal mass in pregnancy. Am $\mathbf{J}$ Obstet Gynecol. 2011 Aug;205(2):97-102. 
7.Hakoun AM, AbouAl-Shaar I, Zaza KJ, Abou-Al-

Shaar H, MN AS. Adnexal masses in pregnancy: An updated review. Avicenna J Med. 2017 OctDec;7(4):153-57.

8.Ray JG, Vermeulen MJ, Bharatha A, Montanera WJ, Park AL. Association Between MRI Exposure During Pregnancy and Fetal and Childhood Outcomes. JAMA. 2016 Sep 6;316(9):952-61.

9.Spitzer M, Kaushal N, Benjamin F. Maternal CA125 levels in pregnancy and the puerperium. $\mathrm{J}$ Reprod Med. 1998 Apr;43(4):387-92.

10.American College of O, Gynecologists Committee on Gynecologic P. Committee Opinion No. 477: the role of the obstetrician-gynecologist in the early detection of epithelial ovarian cancer. Obstet Gynecol. 2011 Mar;117(3):742-6.

11.Woo YL, Kyrgiou M, Bryant A, Everett T, Dickinson HO. Centralisation of services for gynaecological cancers - a Cochrane systematic review. Gynecol Oncol. 2012 Aug;126(2):286-90.

12.No G-tG. Management of suspected ovarian masses in premenopausal women.

13.Obstetricians ACo, Gynecologists. The role of the obstetrician-gynecologist in the early detection of epithelial ovarian cancer in women at average risk. AGOC Committee Opinion. 2017;716(1):1-4.

Kaijser J, Sayasneh A, Van Hoorde K, GhaemMaghami S, Bourne $\mathrm{T}$, Timmerman $\mathrm{D}$, et al. Presurgical diagnosis of adnexal tumours using mathematical models and scoring systems: a systematic review and meta-analysis. Hum Reprod Update. 2014 May-Jun;20(3):449-62.

14.Meys EMJ, Jeelof LS, Achten NMJ, Slangen BFM, Lambrechts S, Kruitwagen R, et al. Estimating risk of malignancy in adnexal masses: external validation of the ADNEX model and comparison with other frequently used ultrasound methods. Ultrasound Obstet Gynecol. 2017 Jun;49(6):784-92.
15.Viora E, Piovano E, Baima Poma C, Cotrino I, Castiglione A, Cavallero $\mathrm{C}$, et al. The ADNEX model to triage adnexal masses: An external validation study and comparison with the IOTA two-step strategy and subjective assessment by an experienced ultrasound operator. Eur J Obstet Gynecol Reprod Biol. 2020 Apr;247:207-11.

16.Van Calster B, Valentin L, Froyman W, Landolfo C, Ceusters J, Testa AC, et al. Validation of models to diagnose ovarian cancer in patients managed surgically or conservatively: multicentre cohort study. BMJ. 2020 Jul 30;370:m2614 